\title{
AGAINST THEORY: SELECTED "GIRLHOOD" FEMINIST ARTISTIC PRACTICES IN POLAND
}

\begin{abstract}
The mass public protests against introduction of further limitations on women's reproductive rights in 2016 become important moment for the Polish feminist movement. Yet, the movement's structure and semiotic reservoir of justifications has visibly changed in the recent years. The young Polish feminism has become more "girlish" than "womanly". In our paper, we analyze how the "girlhood" artistic practices fit into the renewal of contemporary reflection on the gender roles of women and the Polish feminist movement. We analyzed practices of young Polish artivists, involved in girlhood-feminist collectives, and compared their cultural tactics with those of selfie feminism. The paper focuses on girlhood practices as activities which take place across the individual and collective divide and redefine the public sphere. Demonstrating how these initiatives negotiate the normative cultural system, we present expressions of the girlhood experience and describe its social and structural conditions. We analyze feminist artistic practices as expressible and language-based feminine emancipatory practices, using tools typical of analysis of discourse and, predominantly, linguistic performance.
\end{abstract}

Keywords: girlhood, feminism, artivism, feminist artistic practices, confessionalism

\section{Introduction: feminist artistic practices}

The aim of this article is to analyze "girlhood" artistic initiatives undertaken in Poland after 2016 to find examples of a counter-discourse that opposes the neo-liberal image of the post-feminist "successful girl". ${ }^{1}$ The concept of girlhood is multi-

1 M. Gonick, "Voices in Longitude and Latitude: Girlhood at the Intersection of Art and Ethnography", in: Girlhood and the Politics of Place, ed. by C. Mitchell, C. Rentschler, New York-Oxford: Berghahn Books, 2016, p. 46. 
faceted and applicable in such diverse fields as popular culture, art and feminism. Perceived as a new form of symbolic power, even if not explicitly, girlhood played a pivotal role in the analysis of post-feminism. This new feminist attitude was adopted in post-feminism by the following groups: (1) women, or even girls, with a sense of humor, usually young (contrasted with older and more serious feminists); ${ }^{2}$ (2) young women with a sense of "postmodern irony" that enjoy taking advantage of their bodies ("sophisticated anti-feminism"); and (3) young women that embody the idea of thoughtful empowerment and individualism. ${ }^{3}$ The postfeminist "girl" rejects the grand narrative and high theory of feminism as an outmoded prop and as an already well-covered and thoroughly exploited ground. The girlhood artistic practices in post-2016 Poland reflect a similar shift in attitudes - feminist theory is no longer considered to be a reliable and trustworthy tool for expressing and describing the "new girl's" experiences. A new paradigm of knowledge has emerged from experiences of "girlhood" artistic practices, replacing the feminist theory.

2016 can be the key caesura for the semiotic characteristics of the "girlhood" category in Polish art. Our analysis covers the "girlish" pre-2016 feminist Polish art and artworks created in 2016 or later. The date's significance has its roots in politics. The parliamentary elections of October 2015 resulted in a victory of a right-wing party Law and Justice which soon afterwards proposed to withdraw Poland from the Convention on preventing and combating violence against women and domestic violence, voted to abolish the perinatal care standards by adopting the new act on medical activity (10 June 2016), withdrew emergency over-the-counter contraceptives from the market, and halted the financing of the state-supported in vitro fertilizations. Law and Justice sided with proponents of the abortion ban (pro-life and anti-choice lobby), with individual Law and Justice MPs expressing their support for anti-abortion regulations and proposing a new anti-abortion law (the topic regularly reemerges during parliamentary voting sessions). ${ }^{4}$ These events resulted in a birth

2 See A. McRobbie, "Beyond Postfeminism", Public Policy Research 2011, September-November, p. 180: "What once may have had some role to play on the historical stage is no longer needed: feminism is associated with the past and with old and unglamorous women (like Germaine Greer in the UK or Alice Schwartzer in Germany)".

3 See: A. McRobbie, “More! New Sexualities in Girls' and Womens' Magazines”, in: Back to Reality? Social Experience and Cultural Studies, ed. by A. McRobbie, Manchester-New York: Manchester University Press, 1997; A. McRobbie, "Postfeminism and Popular Culture: Bridget Jones and the New Gender Regime", in: Interrogating Post-feminism: Gender and the Politics of Popular Culture, ed. by Y. Tasker, D. Negra, London: Duke University Press, 2007; A. McRobbie, The Aftermath of Feminism: Gender, Culture and Social Change, Los Angeles-London: Sage, 2009.

4 According to the Polish abortion act (7.01.1993): "A termination of pregnancy may be performed only by a doctor, when: 1) The pregnancy poses a threat to the life or health of the pregnant woman, 2) Prenatal examinations or other medical conditions indicate that there is a high probability of a severe and irreversible fetal defect or incurable illness that threatens the fetus' life, 3) There are reasons to suspect that the pregnancy is a result of an unlawful act" - see: https://www.reproductiverights.org/sites/ crr.civicactions.net/files/documents/Polish\%20abortion\%20act--English\%20translation.pdf (Polish version: http://prawo.sejm.gov.pl/isap.nsf/download.xsp/WDU19930170078/U/D19930078Lj. 
of a new Polish feminist movement whose scale was unprecedented. ${ }^{5}$ A Facebook group "Dziewuchy Dziewuchom" [Girls for Girls] (over 100,000 users) was established to inform and engage girls and women, and get them involved in spontaneous initiatives. Many other similar local groups were also formed around the same time. In addition to demonstrations taking place annually on the International Women's Day ( $8^{\text {th }}$ March), more frequent marches and pickets were organized in multiple cities in response to proposals or passing of new restrictions on the women's rights. ${ }^{6}$ The most recent demonstration ("Black Protest") took place on March, 232018. It was a nation-wide demonstration organized in response to the Law-and-Justice-supported draft bill titled "Stop Abortion" and the letter of Polish bishops of March 18,2018 , in which they called for fast passing of the bill. The mass protests have had a noticeable impact on the world of art, with artists including references to feminism, but at the same time associating their art with "girlhood" rather than "womanhood". Who is the "new girl" in Polish contemporary women's art? What defines the sense of "being a girl"? What kind of reasoning? Is the "girl" still a feminist, and if yes, then in what sense? What is her experience? In our analysis of the girlhood aspect of post-2016 feminist artistic practices, we aim to determine to what extent these activities are still rooted in the culture of individualism (characteristic of post-feminism), which manifests itself in the culturalization of social differences, for which lifestyles are particularly important, ${ }^{7}$ how politically-engaged they are and how they explore current political and social topics.

\section{Methodology}

We focused on the artistic practices, which could be labeled as expressions of "girlhood" sensibilities and easily moved across the boundaries between art, social activism, social media activity and artistic education. We analyzed the activity of young Poznań-based artists born in the 1990s; young women who are still at studying, but

pdf?fbclid=IwAR0hFBSpBc1bHC5vrJs19UWhcknRT4ssGNmfbskxwcMHsiPaITHiMWGp0O4), accessed 7.06.2019.

5 E. Majewska, "Słaby opór i siła bezsilnych. \#Czarnyprotest kobiet w Polsce", in: eadem, Tramwaj zwany uznaniem. Feminizm i solidarność po neoliberalizmie, Warszawa: Instytut Wydawniczy Książka i Prasa, 2017. See also report: E. Korolczuk, B. Kowalska, J. Ramme, C. Snochowska-Gonzalez (eds.), Bunt kobiet. Czarne Protesty i Strajki Kobiet, Gdańsk: Europejskie Centrum Solidarności, 2019; J. Kubisa, K. Rakowska, "Was It a Strike? Notes on the Polish Women's Strike and the Strike of Parents of Persons with Disabilities", Praktyka Teoretyczna 2018, no. 4 (30), pp. 15-50, http:// www.praktykateoretyczna.pl/numery/numery-2018/pt-430-2018/, accessed 7.06.2019.

6 For example, protests against introduction of a stricter antiabortion law took place in April 2016 (in Szczecin, April 3, 2016; in Wrocław, April 9, 2016; in Katowice, April 7, 2016; in Zielona Góra, April 24, 2016), in September and October 2016, culminating in the women's strike on October 3, 2016 ("Black Protest"), attended by over 100,000 people across Poland. Successive strikes were organized again in 2017 and 2018.

7 See: M. Jacyno, Kultura indywidualizmu, Warszawa: Wydawnictwo Naukowe PWN, 2007. 
have become involved in a number of initiatives taking place outside the walls of Poznań University of Arts. We invited them to take part in an in-depth focus group interview (it was conducted in April 2017). We also analyzed the initiatives which took on the "girlish" or "girlhood" label, such as those associated with the theatrical play titled Dziewczyny opisuja świat [Girls Describe the World] (2017) or the Bedtime exhibition (2018). Artists involved in those initiatives deliberately used the category of girlhood as a symbol of the "new feminism" that departs from the model based upon strictly defined sexual and cultural category of "femininity". The juxtaposition of the aforementioned activist practices with Polish selfie-feminism, which was particularly notable in Polish post-2016 art, brings particularly interesting results. Our research focused not so much on visual representations of selfie-feminist art, but the statements, declarations and subjective justifications constituting the discourse of the "girlhood" art. Our methodology for this research is based on discourse analysis and action-oriented analysis of women's art. As feminist art refuses to fit into the structure of the traditional art history, which would like to define it by a set of specific themes and aesthetics features, we decided to analyze it as a cultural practice. ${ }^{8} \mathrm{We}$ took inspiration from Griselda Pollock who strongly emphasizes the contextual aspect of feminist art works (related to production conditions) and underlines their action-oriented nature, i.e. their effects. Hence, the term "feminist art" can be replaced with a more action-oriented phrase- "feminist artistic practices". ${ }^{9}$ This approach to feminist-oriented art makes it possible to notice potentially subversive and emancipatory qualities in works and initiatives which at the first glance seem to be devoid of such qualities, but which can lead to some sort of change when placed in a relevant sociocultural context.

Another important building block of the theoretical framework of our research was the mode of cultural analysis developed by the British cultural studies whose research models allow for determining structural positions of groups in the socio-cultural field. We used the categorization first proposed by Frank Parkin who distinguished between dominant-hegemonic, negotiated and oppositional positions, and whose idea was later adopted by Stuart Hall and other researchers of British subcultures. ${ }^{10}$ We used the concept of the negotiated position, which involves "a mixture

N.Yu. Kryvda, L. Osadcha, “Gender Genealogy of Reading as Cultural Practice”, Anthropological Measurements of Philosophical Research 2017, vol. 11, pp. 84-92.

9 G. Pollock, Vision and Difference: Feminism, Femininity and the Histories of Art, London-New York: Routledge, 2006, pp. 9-10; G. Pollock, "Feminism and Modernism", in: Feminisms: A Reader, ed. by M. Humm, New York: Routledge, 2013, p. 362.

10 See: F. Parkin, Class Inequality and Political Order: Social Stratification in Capitalist and Communist Societies, London: MacGibbon and Kee, 1971; S. Hall, "Encoding/Decoding", in: Culture, Media, Language: Working Papers in Cultural Studies 1972-79, ed. by S. Hall, D. Hobson, A. Lowe, P. Willis, London-New York: Routledge, 1980; P. Cohen, "Subcultural Conflict and Working-Class Community", in: Culture, Media, Language ...; J. Clarke, T. Jefferson, "Working Class Youth Cultures", in: Working Class Youth Culture, ed. by G. Mungham, G. Pearson, London: Routledge, 1976; 
of adaptive and oppositional elements", ${ }^{11}$ to characterize the "girlhood" position in contemporary Polish art.

The particularly confessional and interactive character of girlhood makes it a generative category. It is extracted from conversations and verbal performances, with clearly assigned roles of speakers and listeners, supporters and communities, etc. ${ }^{12}$ The architecture of verbal performance situates the viewers of girlhood artistic activities in a crucial position. According to Rita Charon "[as viewers,] we recognize what parts we play in one another's lives and how entailed we are in our shared creation of meaning. We get to know ourselves as a result of the vision of others, and we are able to donate ourselves as instruments of others' learning". ${ }^{13}$ As researchers, we have also played the role of viewers. We have participated in the process of negotiating and generating the category of girlhood, and we were pulled into conversations about girlhood, just as girls typically are.

\section{Explorations of girlhood in pre-2016 Polish art: affirmation or criticism?}

Pioneering "girlhood" initiatives on the Polish art scene had the two main objectives characteristic for feminist artistic practices: to celebrate the "womanly" traits, focusing on the exploration of "feminine creativity", and to dismantle the existing cultural orders and undermine conventional gender and sexual roles, which enforce or lead to the unequal treatment of women and men ${ }^{14}$ ). In her analysis of Polish girlhood art of 2000-2011, Ewa Tatar defines girlhood as a conscious use of feminist irony in perception of femininity and as a strategy which "put emphasis on acting instead of speaking, on identification instead of adopting external point of view. This perspective calls also for using the theory in practice instead of merely quoting it". ${ }^{15}$ In this perspective, the "girlhood" art appears to be: (1) skeptical about former ways of constructing and speaking about femininity; (2) highly aware of the tools it uses (artists often use theories, apply them in practice, and implement their postulates); (3) active;

S. Hall, T. Jefferson, Resistance Through Rituals: Youth Subcultures in Post-war Britain, London: Hutchinson, 1976.

11 S. Hall, "Encoding/Decoding", p. 127.

12 See: R. Charon, Narrative Medicine: Honoring the Stories of Illness, Oxford: Oxford University Press, 2006; K.M. Langerier, "Performing Narrative Medicine", Journal of Applied Communication Research 2009, no. 37 (2), pp. 151-158.

13 R. Charon, op. cit., p. 10.

14 See: R. Parker, G. Pollock, Framing Feminism: Art and the Women's Movement 1970-1985, London: HarperCollins Publishers, 1987; A. Jakubowska, "Feministyczne interwencje Griseldy Pollock", Rocznik Historii Sztuki 2004, vol. 29, pp. 25-48.

15 E.M. Tatar, “Artystki polskie po 2000 roku”, in: Artystki polskie, ed. by A. Jakubowska, WarszawaBielsko-Biała: Wydawnictwo Szkolne PWN, 2011, pp. 147-148. 
artists attempt to solve problems instead of only talking about them; (4) deliberately childish, humorous, and playful; meant to be fun for artists themselves. ${ }^{16}$

In the early $21^{\text {st }}$ century, Polish artists began to lose interest in the themes characteristic for the critical art, the most discussed Polish art movement of the 1990s. The themes related to bodies, religion and the political transformation become less distinctive, and Polish art becomes increasingly diverse, which makes it hard to identify its one defining trend. ${ }^{17}$ Nevertheless, art critics noted that the role of women's art was pivotal for the period: "The peak of the interest in female artists was the unique phenomena of the early noughties. Female artists had never before been so numerous and so visible in the history of Polish art". ${ }^{18}$ The examples of pre-2016 girlhood practices, although diverse, also in their aesthetics and strategies, stem from the need for critical elaboration on culturally available models and norms of "femininity" and "girlhood". Girlhood and its determination or self-determination signifies rebellion, rejection and resistance to the status quo. A good example of this kind of artistic practice is Anna Okrasko's Female Painter Makes for a Painter's Wife (2003). Okrasko painted the statements she had heard from students and lecturers of the Warsaw's Academy of Fine Arts in the corridor of the university. She included such sentences as: "Female artists don't have nice neat hands and the girls from the painting department are dirty", "The department is unfortunately becoming feminized", "A woman even if she graduates from the academy of fine art will still get married and give birth to a child", "The academy of fine art should be like the army there is no place for babes with complexes who cry after every criticism". Other artist, Agata Biskup used another stereotype-based strategy in her paintings: I co ja teraz zrobię [What can I do now?] (2006), Pingwin [Penguin] (2006), Kwiaty [Flowers] (2006), Chmurki [Cloudlets] (2006), and Pejzaż z balonikami [Landscape with balloons] (2006). She experimented with kitsch and pop culture images, using deliberate infantilization, steeped in sentimentalism and based on naive imagination. ${ }^{19}$ Also Basia Bańda, whose works were often described as commentaries on fears and desires of girlhood, found inspiration in fables, fairy tales and legends mixed with pop-cultural motifs. The artist paints, draws and knits fantastical creatures, but adds also clear references to male and female genitals, e.g. Potwór [Monster] (2003) or Szybko [Fast] (2006). Rather than creating a "new girl", women artists focus on highlighting the obstacles that the $21^{\text {st }}$ -century-women still have to overcome. They remain focused on the issues of sexuality, fears related to socialization, unequal treatment of women and men in public and private spheres of life, popular culture, body and everyday lives, as well as art itself, with its privileged and hidden aspects.

16 Ibid., p. 148.

17 G. Borkowski, M. Branicka, A. Mazur (eds.), Nowe zjawiska w sztuce polskiej po 2000 roku, Warszawa: Centrum Sztuki Współczesnej “Zamek Ujazdowski”, 2007.

18 M. Ujma, “Ani rewolucja, ani konsumpcja”, in: Nowe zjawiska w sztuce polskiej..., p. 48.

19 G. Borkowski, "Świadome infantylizacje i duch lat 70. na Bielskiej Jesieni 2007”, Obieg, http:// archiwum-obieg.u-jazdowski.pl/recenzje/3792, accessed 1.02.2019. 


\section{"Pink, Glitter, Anti-fascism" and education}

The subversive potential of girlhood as a category depends on its indefinite character and the fact that the category cannot be assigned one unequivocal meaning. A girl can grow up to become anyone: a mother, a politician, a lover, a fighting feminist, an eternal little girl, a tomboy, or one of many other figures which are always interconnected and mixed, but never permanent. It is not only the matter of passage of time and growing-up, but foremost the issue of uncertainty, haphazardness, elusiveness and instability that constitute the "girlhood" attitude, which can be regarded as a liminal experience and, therefore, a threat to the dominant social order. ${ }^{20}$ The ambivalence of this indefinite character situates girlhood practices in opposition to the political and social responsibilities imposed on individuals in contemporary society. How do artists construct this experience? How do they communicate it to their audiences?

The demonstrations, marches and pickets held across Poland in the last three years have been organized under the following slogans: in 2016, "Abortion Protects Lives" (Warsaw), "United Against Rape Culture" (Poznań), "Our Boundaries Don't Divide Us" (Kraków), "Women's Safety" (Katowice); in 2017, "Stop Government's Oppressiveness" (Wrocław, Łódź, Lublin, Warsaw, Poznań), "United Under One Umbrella" (Tri-city), "Again the Same Story, Sister and Mother" (Toruń); in 2018, "One Hundred Years of Women's Right. We Want More!" (Katowice), "Abortion, Not Police" (Warsaw), "Abortion Free of (Court) Judgments" (Wrocław), "United For a Better World" (Toruń). Combination of artistic and activist initiatives seems to be one of the essential qualities of the post-2016 "girlhood" art (or at least of some of its projects). The slogan of the 2018 Poznan Manifa ${ }^{21}$-Pink, Glitter, Anti-fascismis an interesting example of combing elements which are typically associated with girlhood, or even girly, aesthetics (pink, glitter) with the left-wing objection to discriminatory ideologies.

The activities undertaken by girlhood collectives after 2016 do not match the traditional definitions of art taught at Poznań University of Arts. When asked to list their main areas of activity, our speakers (young students, feminist activists and artists) mentioned the following: involvement in Manifa and the Black Protest, work with local communities in one of the districts of Poznań, fighting to protect the Białowieża Forest, ${ }^{22}$ the formation of an ephemeral collective "Życie na fali" (organization of

20 V. Turner, The Ritual Process: Structure and Anti-Structure, London-New York: Routledge, 2017.

21 Manifa is an annual nationwide feminist demonstration organised in Poland since 2000 on March 8 (International Women's Day).

22 The Camp for the Forest is a civic mobilization movement formed to protect Białowieża Forest against the decision of the then Polish Environment Minister, Jan Szyszko (in office from November 2015 to January 2018), on cutting down trees in the areas of Białowieża Forest which were affected by the European spruce bark beetle outbreak. Mass civic protest activities culminated in a ruling of the Court of Justice of the European Union of April 17, 2018, which stated that the increased logging 
participatory dance parties), publishing of zines, and many others. However, the fact that these young women are still students informs the framework of their activities, due to their dependency in the context of their relation with the university. They define their positions at the University of Arts and within the world of art in a similar way, that is, as ambivalent. On one hand, our interviewees do not consider themselves as "artists" and openly admit the following:

Speaker 1: I have this feeling that I don't make art at all. And it's like I'm a student of this school [University of Arts] and some things happen, but I don't feel that I am an artist. [...] I would never call myself that.

On the other hand, they say (with resentment) that the art community does not understand their initiatives:

Speaker 1: It seemed to be totally... I think that, because of what we have done in Poznan, we are treated like aliens, and the art community doesn't think our work is art...

The young artists' dependence on the university situates them in the center of cultural processes of production and reproduction, driven by the state education system. In this case, it can be stated, recalling the terms typically associated with poaching practices, that the girls employ discreet tactics, such as studying by evading the system, but also engage in resistance and contestation. ${ }^{23}$ The girls themselves use the term "make deals" when discussing this tactic, defining it as a way of making transactions, using a specific form of currency as many times as possible, that is, as long as the other party continues to accept it. In the context of "making deals", for the girls, the currency in question consist of their social initiatives and artistic practices, which are imbued with social and participatory significance. They attempt to make such "deals" in class, which are typically passed by producing standard "artworks" and "objects". "Making deals" allows them to be part of the system of art education and maintain their student status (with its advantages and disadvantages), but also to go beyond the system, observe it from the outside, and even defy it. When "making deals" with professors becomes impossible, they fail their classes, take holiday leaves or remain in a standstill, with unfinished studies. The girls regard the acts of "making deals", acts of opposition and resistance, as modes of acting, but also as a way of adopting an ideological stance within the education system:

Speaker 2: [...] it seems that we work a lot with one another. And we have built some sort of confidence because of that, as we work in groups and collectives, and we also often don't put

in Białowieża Forest constituted a breach of the EU regulations. The Camp for the Forest, located in town Teremiski, is home to protesters and voluntary participants who arrive and leave on a rotating basis.

23 M. de Certeau, The Practice of Everyday Life, London: University of California Press, 2011. 
our names on the projects. And I think there is this strength in us, that we don't let ourselves simply... We don't create works for the theme. ${ }^{24}$

"Not creating works for the theme" is an act of opposition to the "cult of personality", on which the students comment: "the cult is very much kept alive here, at our university. Just putting in your head the conviction that you are the best" ${ }^{25}$ Concentration on the author's original and individualistic artistic statement is considered to be a systemic feature of Poland's art education, which provokes many oppositional attitudes: rejection, resignation, tiredness, protest and contestation:

Speaker 2: I'm sick and tired of it and so are the girls, I'm certain they are. And, interestingly, recently I've noticed that our community is getting tired, no one wants to put their name on anything, and no one wants to speak to the media...

Speaker 1: Yes, this year there was a huge problem because no one wanted to be the face of anything.

Besides discreet tactics, the "girls" engage also in more explicit acts of resistance. For example students' battle against the new regulation which allowed to fire lecturers who are 70 years old or older, ${ }^{26}$ or creation of Pracownia Studencka Monitor [Monitor Students Laboratory], a grassroots initiative that aims to democratize the rights and relations at the University of Arts. This conscious approach involving community-based work, group protests, collaboration, and resignation from the author's individual signature is indicative of processes of integration and differentiation. The girls admit they tend to keep their distance from the lecturers and students at the university, as well as from the main sphere of Poland's art world. On the other hand, their alienation is collective in character; the community-based model of their activities is crucial for structuring their everyday practices. The girls "do things together", "help one another", and "form groups", ${ }^{27}$ They recognize this "style" of activity as typical of social movements rather than artistic circles.

Speaker 1: As far as activism is concerned, I have learned a lot from people who had done it before and the people we're working with now, they have given us the know-how. Sure, they are people that we have personal relations with, so there are good and bad sides to it, but you just learn a lot from the people you work with.

24 Doing "works for the theme" is a typical mode of work practiced in the laboratories of the Poznan University of Arts. At the beginning of the academic year, several themes are chosen for the students to produce works on their basis.

25 Quotation from the in-depth interview conducted on April 29, 2018.

26 The protest was focused on defending one of the Poznań university professors, Jarosław Kozłowski, one of the most respected and inspiring lecturers, and a prominent figure in Poland's conceptual art scene. The protest was successful.

27 Quotation from the in-depth interview conducted on April 29, 2018. 
For our interviewees, the experience of collectivism at the Camp for the Forest was the most remarkable thing:

Speaker 3: For me, it was very important, the way it worked. I spent there 10 days in total, but when I saw, you know, [...] the fact that such a big group was formed, that it is active to this day, that it has been successful, and that there was this battle and it brought some results.

The young activists are fully aware of the fact that the "girlhood" art coupled with social activism is becoming a trend. "Because this comes up [...] in feminist circles, this hype about girlhood, [...] there is a lot of hype about activism, socially-conscious initiatives $[\ldots]^{\prime \prime},{ }^{28}$ and they regret that these initiatives are rarely preceded by a more in-depth diagnosis of actual needs of local communities. On the other hand, this mode of operation, which is typical of social movements, is immensely inspiring and serves as a real testing ground for "girlhood" as a category. It is connected with group-based mode of work, which is typical of activist communities, and which produces meanings related to practices of collaboration, mutual help and support, which all fall into the definition of "sisterhood".

\section{Precarization and sisterhood}

The perspective that reveals how the category of girlhood is taken over by mainstream hegemonic discourses often highlights the precarious status of girlhood, which is economically uncertain, suspended between adolescence and adulthood. In her interpretation of Girls TV series (2012-2017) Lauren J. DeCarvalho states that thematization of the girls' workplace struggles during the post-recession era makes us more accustomed to the new social order (e.g. precarization of female jobs). The analysis presents Girls as a pop-cultural text that ultimately departs from the models of a new "sensitive man" and a "liberated woman" towards a figure of a girlish postgraduate and the post-feminist condition of suspension, high hopes and never-ending fun. ${ }^{29}$ For Poznań-based girlhood collectives, being suspended between the roles of a university student and a jobholder constitutes the basic platform of shared experience, but one, which is undergone more willingly in groups than individually. Collective work and individualistic career are the opposite ends of the polarization of meanings which structure the girls' experiences related to work, university life and art. The practice of organizing protests (Manifa, the Black Protest, and the Camp for the Forest) serves to thematize meanings and forms related to collective models of work. Interestingly, when we have started our research, the biggest Polish social media group for women "Dziewuchy Dziewuchom" [Girls for Girls], which was the catalyst for organization of mass protests against the proposed stricter antiabortion law in Poland, was

28 Quotation from the in-depth interview conducted on April 29, 2018.

29 L.J. DeCarvalho, "Hannah and Her Entitled Sisters: (Post)Feminism, (Post)Recession and Girls", Feminist Media Studies 2013, vol. 13 (2), pp. 367-370. 
privatized (the name was registered and now belongs to private persons). This event was widely debated in Polish media and women's communities. One of the most interesting theories offered as an explanation for this "privatization" of the group is the phenomenon of so-called "civic privatism", i.e. incorporating corporate business work and management models into social movements. ${ }^{30}$

Overcoming difficulties connected with precarization of the girls' social condition is possible by through solidarity of sisterhood. The girls emphasize the increasingly difficult necessity to maintain balance between having to "pay the rent" and accepting the conditions and contexts of work (which they oppose on an ideological level). As for the latter, they refer to the concept of "making do", which they find essential, and moving beyond the perspective of "men explaining things to me", ${ }^{31}$ collaborating, helping one another and empathizing:

Speaker 1: It's all about sisterhood and finding reinforcement out there. But you can't separate it from what happens at work, I don't know, from what happens at home, at the university.

Girlhood regarded as sisterhood is inseparably connected with a collective and anti-individualistic attitude, and allows for a conscious redefining of feminism.

Speaker 2: Defining things always limits you in a way, and so does naming things, like what a feminist is like, because when she's this, then she's not that, etc. And maybe we are ignoring those definitions in order not to limit our vision, stay in the bigger picture, and remain active in a larger number of fields.

Speaker 1: It's somehow related to it, to collective work and to being against the cult of personality, which is very much kept alive here, at our university. Just putting in your head the conviction that you are the best $[\ldots]$.

By adapting the research models based on the British cultural studies, it is possible to classify this kind of position as a negotiated one; ${ }^{32}$ partly adaptive and partly oppositional. In this perspective, cultural practices, which are indicative of the negotiated position, constitute a "game" played with the semiotic resources of the dominant culture, and in the case of girlhood, a game whose outcome remains unknown, as girlhood is a category whose semiotic capacity is so large that it can contain many pairs of contradictory meanings. Two of such pairs seem to be particularly interesting: (1) girlhood as a subculture vs. girlhood as a mockery of a subculture; (2) girlhood as a form of community-based sisterhood (artivist collectives) vs. girlhood as

30 E. Korolczuk, "Dziewuchy Dziewuchom - baśń o pewnej prywatyzacji z nieprostym morałem", Krytyka Polityczna, 23.04.2018, http://krytykapolityczna.pl/kraj/dziewuchy-dziewuchom-basno-pewnej-prywatyzacji-z-nieprostym-moralem/, accessed 1.03.2019.

31 During the interview, the girls deliberately referred to the title of Rebecca Solnit's book, Men Explain Things to Me (Chicago: Haymarket Books, 2015).

32 See: F. Parkin, op. cit.; S. Hall, “Encoding/Decoding”; P. Cohen, op. cit.; S. Hall, T. Jefferson, op. cit. 
a confessional individualistic position (selfie-feminism, sometimes linked to the Sad Girl Theory $\left.{ }^{33}\right)$.

\section{Confessionalism}

Girlhood as subculture is a category first introduced in recent years by women's lifestyle magazines, such as "F5" or "Showroom". It is a prime example of a cultural construct taken over by pop-cultural mechanisms, with its elementary features (such as collectivism and sisterhood) reused and set in a transformed semiotic context - not the context of critical feminist consciousness, but of a subculture, a strictly defined formation of styles and attitudes. This shift is also caused by "labeling", a media mechanism which neutralizes social processes by providing their more precise semiotic definitions (typically pejorative ones), e.g. identifying them as forms of deviation, or vandalism, etc., which ensures that the lifestyle-related aspect of girlhood are emphasized. ${ }^{34}$ A stylistically defined group can be identified with just "one glance", and thus easily neutralized.

When girlhood, as a subculture, first appeared in the media, it was met with rejection, mockery, contempt, and sarcasm: girlhood as a subculture was seen as an unsophisticated intellectual gimmick. Emergence of Polish selfie-feminism provoked similar reactions. The many critical opinions expressed in the public debate defined it as narcissistic, involving sexualization of on-line depictions of female bodies, available only to attractive girls, and superficial. The strategies of selfie-feminism were regarded as means of expressing one's style (whose domain is body) rather than adopting a critical feminist position (whose domain is mind).

However, the concepts of girlhood as community-based sisterhood and as a confessional individualistic position (selfie-feminism, sad girl theory) share the same essential operational feature: confessionalism. That is why defining girlhood is so difficult; all of its semiotic variations are based upon the same qualities: confessionalism, community, the idea of "being together", etc. As noted in Audrey Wollen's Sad Girl Theory, which initially inspired Polish selfie-feminism artists, confessionalism - regarded as an act of transgression, shifting from the private to public sphere with a confession of sadness — creates a basic communication situation. Even though sadness and despair belong to the sphere of privacy and individualism, they are communicated, revealed, confided, and narrated, to eventually become a public matter. These acts do not fit in conventional speech contexts characterizing public communication. The way bloggers, Instagrammers and artists draw inspiration from the Sad Girl Theory is not compliant with the masculine communication styles that dominate

33 Cf.: Artist Audrey Wollen on the Power of Sadness, 20.07.2015, https://nylon.com/articles/audrey-wollen-sad-girl-theory, accessed 12.01.2018.

34 S. Hall, "Deviance, Politics and Media", in: The Lesbian and Gay Studies Reader, ed. by H. Abelove, M.A. Barale, D.M. Halperin, New York-London: Routledge, 1993, pp. 62-90. 
in the public space. They communicate and interact using the new media-by means of photos and posts published on Instagram, Tumblr, and Facebook, which are often regarded as individualistic manifestations of privacy and acts of "unreal" communication. The Polish selfie feminists are foremost inspired in the way in which Wollen's theory rearranges the communication situation. It is not the man who portrays the girl by transforming her into a sexual object; instead, she herself displays the image of her body and experiments with the conventions of demonstrating her girlish qualities. ${ }^{35}$ A girl is on her own (selfie) and in public at the same time (on-line). Every well-known selfie artist will say she feels a sense of belonging to the community of girls, which would not exist without the Internet. As Jessalynn Keller noted in her research of girls' blogs, it is "invisible" activism, as it does not use (or does not use often) any typical, traditional methods of activism, such as legal challenges or commercial boycotts. ${ }^{36}$ But the experience is feminist, changing the way we look at girlhood and art. Consequently, neither "sad girls" and selfie-feminists nor artivists, act alone. All categories of girlhood are based upon girls' communities. All of them use confessionalism as their main means of expression. What is worth noting, Angela McRobbie's study on the culture of working class girls of the 1970s indicated that confessionalism was one of the essential features of "girlhood" communities. In that case, those communities were deeply rooted in social and economic hierarchies of patriarchy and reflected the semantic structures of the patriarchal culture. ${ }^{37}$

Selfie feminism and artivism are both equally active in their use of social media mechanisms. Organization of the Black Protest and the Camp for the Forest would have been impossible, at least in the same form, without the Internet. Relationships built by means of new media in the context of artivist initiatives are no more lasting than the ones formed in the comments written under expressions of selfie-feminism. Our interviewees highlighted the fact that although social media make collective work much easier, they also diffuse responsibility. The girls rarely know the people they work with, and sometimes there is an impression that "things happen on their own".

\section{Departure from "feminine feminism"}

The "girlhood" artivism and selfie feminism have one thing in common-they separate themselves from the earlier versions of "feminine feminism". "Maintaining" the state of girlhood (often for a longer period of time; the category of girlhood remains

35 Z. Krawiec, "Smutne dziewczyny", Dwutygodnik 2017, no. 203, https://www.dwutygodnik.com/ artykul/6980-smutne-dziewczyny.html, accessed 1.02.2019.

36 J. Keller, "Making Activism Accessible: Exploring Girls' Blogs as Sites of Contemporary Feminist Activism", in: Girlhood and the Politics of Place, ed. by C. Mitchell, C. Rentschler, New York-Oxford: Berghahn Books, 2016, p. 261.

37 A. McRobbie, "Working Class Girls and the Culture of Feminity", in: Women Take Issue: Aspects of Women's Subordination, ed. by Women's Studies Group CCS University of Birmingham, LondonNew York: Routledge, 2012, pp. 96-108. 
valuable to some Polish artists who were born in the $1970 \mathrm{~s}^{38}$ ), returning to girlhood or never growing out of it at all constitute symbolic acts of preserving the moment of entering into the cultural and hegemonic structures based upon femininity and "feminine feminism". In the sphere of symbolic artistic manifestations, the act of "maintaining" the state of girlhood involves using objects typically associated with girlhood as a period of life, such as in Aleksandra Jakubczak's play Dziewczyny opisuja świat ${ }^{39}$ or Zofia nierodzińska's curatorial project $\left(\right.$ Bedtime $\left.e^{40}\right)$. Both of these projects present girlhood in a very similar fashion, i.e. as a liminal state, an undefined moment of transition. In the case of Jakubczak the state of being a girl is not even defined in terms of gender; a girl is "a bit of a boy". Being a tomboy also can be considered in the framework of the structural condition of the working-class: "Working-class girls cannot necessarily afford the trappings of the girly-girl". ${ }^{41}$

In Bedtime, the artists say: "You are young and you have no influence", "one day you live in a pink bedroom, and the next day you find it embarrassing", "you fall into the tentacles of the market, but you have no money". ${ }^{42}$ The objects used in these projects appear to come from the adolescence of contemporary twenty-somethings, i.e. from the 1990s. Polish "girlhood" artists, as in the case of the two above-mentioned projects, employ a scientific-cognitive strategy to reconstruct the specific cultural-geographical context of their adolescence. Both girlhood artivists and selfie-feminists use research and discovery to demonstrate girlhood as a stage of one's development. The girl is a subject "to be made" (constructive) and to "be discovered" (objective). She is "out there", she can be called in, performed, replayed ("memories are performed" in Jakubczak's play). The nature of activities associated with discovering is collective, community-based, and confessional (sharing secrets, compulsive talking, belaboring topics), and thus interactive. These activities create a nostalgic reference to the material arrangement typical of a specific generational and interpretative community (Hoop cola, takeaway coffee, "Piotr i Pawel" supermarket che$\left.\mathrm{ese}^{43}\right)$. In Jakubczak's play, girls give examples of material products reminiscent of the 1990s capitalism, which at that time were overwhelmingly desired (including by

38 For instance: Iwona Demko, Agata Zbylut and Aleksandra Ska, who perceive girlhood as a strategy which allows to undermine patriarchal perspectives and as an opposition to the discourse proposed by the authorities.

39 It is a play based on girls' diaries written in the 1990s and 2000s.

40 Bedtime is an art project of Polish artists from the Dziewczyństwo Collective and the Cover Berlin group, curated by Zofia nierodzińska. It was inaugurated with an exhibition held in the Arsenal Municipal Gallery in Poznań on September 7, 2018. The project is to include "sleepovers", i.e. nightly initiatives undertaken by artists and visitors in the gallery, in reference to teenage girls' sleepovers.

${ }_{41}$ S. Holland, J. Harpin, "Who Is the 'Girly' Girl? Tomboys, Hyper-femininity and Gender", Journal of Gender Studies 2013, vol. 24 (3), p. 299.

42 Quotations from artists included in: N. Mazur, "Dziewczyny zapraszają do łóżka w Galerii Arsenał", Gazeta Wyborcza, 7.09.2018, http://poznan.wyborcza.pl/poznan/7,105531,23871043,dziewczynyzapraszaja-do-lozka.html, accessed 1.02.2019.

43 A Polish supermarket chain established in 1990. 
working-class girls). Entanglement in capitalist mechanisms is a fact (as in the case of selfie-feminism or Sad Girl Theory): the girls are fully aware that in the 1990s they would not have been able to express their total opposition to the capitalist system. They do not want to spend their time on inventing new strategies; they accept the fact that they have adopted a negotiated position, performed on the basis of market's resources, not outside of them.

However, the way of explaining girlhood in the terms of negotiating position against the dominant system belongs to the structuralist spirit of cultural studies. ${ }^{44}$ In its Neogramscian version this kind of explanation does not necessarily take into account the materiality of subjects' positions. Meanwhile, the artistic practices we have described above, clearly evoke or re-arrange girls' past experiences, using material requisites. In this context, they can be conceptualized in the terms of new materialism, where, as Dorota Golańska notes: "The artistic process is [...] productive and responsive thinking with the whole body, along with its complex and multidimensional sensual instrumentarium and at the same time thinking with material or fabric, as well as thinking with tools and their interaction with matter". ${ }^{45}$ In the materially oriented artistic practices "evoking and maintaining "feelings" "46 plays the crucial role. In the case of Jakubczak's work and of Bedtime exhibition, arranging situations as affective re-living is the basic artistic strategy.

\section{Conclusion}

Artivism and selfie feminism_-Polish artistic initiatives which at the first glance seem to be the opposites of each other-share a set of common features: confessionalism, sisterhood, and nostalgia for capitalism, which is typical of working class. Their position in the social field can be defined as negotiated - it is marked by discreet tactics of "making deals" with the (artistic and educational) system; and a rich repertoire of attitudes (from rejection, resignation, and tiredness, to protest and contestation). Girlhood as experience is lived, performed, recalled, enunciated, and shared. In the semiotic field of its discursive expressions, girlhood rejects the old feminism in two ways: (1) by disavowing the neoliberal model of career associated with the old feminism, and (2) by rejecting the structure of knowledge on which it was based. The first one results from articulation of the girls' experience as precarious. Precarization as cultural category is present in the semiotic field of both, artivism and selfie feminism, serving as a category describing the primary and fundamental experience of girls. Precarization determines almost all qualities of girlhood, as well as the girl's

${ }_{44}$ See: S. Hall, "Cultural Studies: Two Paradigms", Media, Culture and Society” 1980, no. 2.

45 D. Golańska, "O praktykach i procesie. Badania artystyczne a mechanizmy wytwarzania wiedzy w ujęciu nowomaterialistycznym", in: Feministyczne nowe materializmy: usytuowane kartografie, ed. by O. Cielemęcka, M. Rogowska-Stangret, Lublin: E-naukowiec, 2018, p. 206.

46 Ibid., p. 211. 
relations in the social, economic and cultural field. It structures girls' experiences and at the same time serves as an articulation of girls' shared experiences. Precarious conditions of girlhood determine also the main adversary of the girl - the subject of the second-wave feminism, the career woman; autonomous, modern, and taking control of the situation. Rejection of the subject of feminism necessitates rejection of the feminist theory. In the semiotic field, the "girlhood" feminism's function as a knowledge structure is particularly important. Selfie feminism and artivism are most often criticized as sources of knowledge - in the social media, they are often associated with low quality, too simplistic arguments, and contradictory propositions. However, feminism as a theory no longer operates as a compass for young artivists and selfie feminists. Perceived as vehicles of structures of meaning, these movements become new communities of knowledge, deeply structured by the new media environments. Feminist theory is recognized as oppressive, while a postulate of formulating the universal feminist theory, as naïve. On the other hand, creation of local and dispersed concepts addressed to particular individuals and communities is considered to be both possible and functional in the context of "making deals" within the system.

Is the political feminist movement possible on the base of such dispersed and local feminist concepts? What are the conditions of its social and political efficacy? And would it be able to act politically without the critical and unifying structures of knowledge?

\section{Bibliography}

Artist Audrey Wollen on the Power of Sadness, 20.07.2015, https://nylon.com/articles/audrey-wollen-sad-girl-theory, accessed 12.01.2018.

Borkowski G., “Świadome infantylizacje i duch lat 70. na Bielskiej Jesieni 2007”, Obieg, http://archiwum-obieg.u-jazdowski.pl/recenzje/3792, accessed 1.02.2019.

Borkowski G., Branicka M., Mazur A. (eds.), Nowe zjawiska w sztuce polskiej po 2000 roku, Warszawa: Centrum Sztuki Współczesnej “Zamek Ujazdowski”, 2007.

Charon R., Narrative Medicine: Honoring the Stories of Illness, Oxford: Oxford University Press, 2006.

Clarke J., Jefferson T., "Working Class Youth Cultures", in: Working Class Youth Culture, ed. by G. Mungham, G. Pearson, London: Routledge, 1976, pp. 138-159.

Cohen P., "Subcultural Conflict and Working-Class Community", in: Culture, Media, Language: Working Papers in Cultural Studies 1972-79, ed. by S. Hall, D. Hobson, A. Lowe, P. Willis, London-New York: Routledge, 1980, pp. 66-75.

DeCarvalho L.J., "Hannah and Her Entitled Sisters: (Post)Feminism, (Post)Recession and Girls", Feminist Media Studies 2013, vol. 13 (2), pp. 367-370.

de Certeau M., The Practice of Everyday Life, London: University of California Press, 2011. Golańska D., "O praktykach i procesie. Badania artystyczne a mechanizmy wytwarzania wiedzy w ujęciu nowomaterialistycznym”, in: Feministyczne nowe materializmy: usytuowane kartografie, ed. by O. Cielemęcka, M. Rogowska-Stangret, Lublin: E-naukowiec, 2018, pp. 196-219. 
Gonick M., "Voices in Longitude and Latitude: Girlhood at the Intersection of Art and Ethnography", in: Girlhood and the Politics of Place, ed. by C. Mitchell, C. Rentschler, New York-Oxford: Berghahn Books, 2016, pp. 38-50.

Hall S., "Encoding/Decoding", in: Culture, Media, Language: Working Papers in Cultural Studies 1972-79, ed. by S. Hall, D. Hobson, A. Lowe, P. Willis, London-New York: Routledge, 1980, pp. 117-127.

Hall S., "Deviance, Politics and Media", in: The Lesbian and Gay Studies Reader, ed. by H. Abelove, M.A. Barale, D.M. Halperin, New York-London: Routledge, 1993, pp. 62-90.

Hall S., Jefferson T., Resistance Through Rituals: Youth Subcultures in Post-war Britain, London: Hutchinson, 1976.

Hall S., "Cultural Studies: Two Paradigms", Media, Culture and Society 1980, no. 2, pp. 5772.

Holland S., Harpin J., "Who Is the 'Girly' Girl? Tomboys, Hyper-femininity and Gender", Journal of Gender Studies 2013, vol. 24 (3), pp. 293-309.

Jacyno M., Kultura indywidualizmu, Warszawa: Wydawnictwo Naukowe PWN, 2007.

Jakubowska A., "Feministyczne interwencje Griseldy Pollock", Rocznik Historii Sztuki 2004, vol. 29 , pp. 25-48.

Keller J., "Making Activism Accessible: Exploring Girls' Blogs as Sites of Contemporary Feminist Activism", in: Girlhood and the Politics of Place, ed. by C. Mitchell, C. Rentschler, New York-Oxford: Berghahn Books, 2016, pp. 261-278.

Korolczuk E., "Dziewuchy Dziewuchom - baśń o pewnej prywatyzacji z nieprostym morałem”, Krytyka Polityczna, 23.04.2018, http://krytykapolityczna.pl/kraj/dziewuchy-dziewuchom-basn-o-pewnej-prywatyzacji-z-nieprostym-moralem/, accessed 1.03.2019.

Korolczuk E., Kowalska B., Ramme J., Snochowska-Gonzalez C. (eds.), Bunt kobiet. Czarne Protesty i Strajki Kobiet, Gdańsk: Europejskie Centrum Solidarności, 2019.

Krawiec Z., "Smutne dziewczyny", Dwutygodnik 2017, no. 203, https:/www.dwutygodnik. com/artykul/6980-smutne-dziewczyny.html, accessed 1.02.2019.

Kubisa J., Rakowska K., "Was I a Strike? Notes on the Polish Women's Strike and the Strike of Parents of Persons with Disabilities", Praktyka Teoretyczna 2018, vol. 4 (30), pp. 15-50, http:// www.praktykateoretyczna.pl/numery/numery-2018/pt-430-2018/, accessed 7.06.2019.

Kryvda N.Yu., Osadcha L., "Gender Genealogy of Reading as Cultural Practice", Anthropological Measurements of Philosophical Research 2017, vol. 11, pp. 84-92.

Langerier K.M., "Performing Narrative Medicine", Journal of Applied Communication Research 2009, no. 37 (2), pp. 151-158.

Majewska E., "Słaby opór i siła bezsilnych. \#Czarnyprotest kobiet w Polsce", in: eadem, Tramwaj zwany uznaniem. Feminizm i solidarność po neoliberalizmie, Warszawa: Instytut Wydawniczy Książka i Prasa, 2017, pp. 25-42.

Mazur N., "Dziewczyny zapraszają do łóżka w Galerii Arsenał”, Gazeta Wyborcza, 7.09.2018, http://poznan.wyborcza.pl/poznan/7,105531,23871043,dziewczyny-zapraszaja-do-lozka. html, accessed 1.02.2019.

McRobbie A., "Beyond Postfeminism”, Public Policy Research 2001, September-November, pp. 179-184.

McRobbie A., “More! New Sexualities in Girls' and Womens' Magazines”, in: Back to Reality? Social Experience and Cultural Studies, ed. by A. McRobbie, Manchester-New York: Manchester University Press, 1997, pp. 190-209. 
McRobbie A., "Postfeminism and Popular Culture: Bridget Jones and the New Gender Regime", in: Interrogating Post-feminism: Gender and the Politics of Popular Culture, ed. by Y. Tasker, D. Negra, London: Duke University Press, 2007, pp. 27-39.

McRobbie A., The Aftermath of Feminism: Gender, Culture and Social Change, Los Angeles-London: Sage, 2009.

McRobbie A., "Working Class Girls and the Culture of Feminity", in: Women Take Issue: Aspects of Women's Subordination, ed. by Women's Studies Group CCS University of Birmingham, London-New York: Routledge, 2012, pp. 96-108.

Parker R., Pollock G., Framing Feminism: Art and the Women's Movement 1970-1985, London: HarperCollins Publishers, 1987.

Parkin F., Class Inequality and Political Order: Social Stratification in Capitalist and Communist Societies, London: MacGibbon and Kee, 1971.

Pollock G., "Feminism and Modernism", in: Feminisms: A Reader, ed. by M. Humm, New York: Routledge, 2013, pp. 362-366.

Pollock G., Vision and Difference: Feminism, Femininity and the Histories of Art, LondonNew York: Routledge, 2006 (1988).

Solnit R., Men Explain Things to Me, Chicago: Haymarket Books, 2015.

Tatar E.M., "Artystki polskie po 2000 roku”, in: Artystki polskie, ed. by A. Jakubowska, Warszawa-Bielsko-Biała: Wydawnictwo Szkolne PWN, 2011, pp. 145-158.

Turner V., The Ritual Process: Structure and Anti-Structure, London-New York: Routledge, 2017.

Ujma M., “Ani rewolucja, ani konsumpcja”, in: G. Borkowski, M. Branicka, A. Mazur, Nowe zjawiska w sztuce polskiej po 2000 roku, Warszawa: Centrum Sztuki Współczesnej "Zamek Ujazdowski”, 2007, pp. 48-52. 